\author{
21 - 23 JUNE 2019 \\ VIENNA, AUSTRIA
}

\title{
Impact of meditation on state trait anxiety of teachers
}

\author{
Manju Gundumogula ${ }^{1, *}$ and Rojina Prusty ${ }^{2}$ \\ ${ }^{1} \mathrm{PhD}$ Scholar, Department of Sociology, SLTC Doctoral School, Lorraine University, France. \\ ${ }^{2} \mathrm{PhD}$ Scholar, Departmnt of Education, Osmania University, Hyderabad, India \\ *Corresponding author
}

\begin{abstract}
Teachers face rising pressure in their job: In a connected, computerized world all information's can be found one click away in the internet, all achievements can be compared, there is a rising competition among the students and among the schools, students get more and more demanding and challenging for the teachers. The aim of present study is to find out, if the anxiety level differs between teachers that practice meditation and those who do not. To select the samples the purposive sampling method was used. The sample included 60 government school teachers, 35 male and 25 female, East Godavari District, Andhra Pradesh state in India. Among them 30 meditative teachers, who are practicing Sahaja Yoga meditation about 10 years and more and 30 non-meditative teachers. Age of the subjects ranged from 35 to 59 years. The data was collected through State Trait Anxiety Test, in a questionnaire method. SPSS statistic software was used for the interpretation of the data and the statistical tools mean, Standard Deviation and T-Value and t-ratio were employed at .05 level confidence. The statistical analysis shows that there exists significant difference on anxiety level among meditative teachers and non-meditative teachers. Moreover both state and trait anxiety level of non-meditative teachers is higher than meditative teachers. Keeping this in view, it can be concluded that Sahaja Yoga Meditation practice helps the teachers to overcome their anxiety level and hence it can be used as a therapeutic technique for teachers to keep their mental health peaceful and balanced.
\end{abstract}

Keywords: Sahajayoga meditation; anxiety level; mental health; therapeutic technique; school teachers

\section{Introduction}

At present, we are in a modern and computerized era, with new technological innovations, which is bringing a considerable progressive advancement and creating new opportunities with lots of infrastructure changes in every field. Its effect is also clearly visible in our education sector, where teaching is becoming a challenge for teachers in order to make their students ready to face this situation and to get the victory.

Teaching is a Nobel profession, however teaching has been identified as a stressful occupation (Cacha, 1981; Farber \& Miller, 1981; Landsman, 1978; Paine, 1981; Russell et al, 1987; Cooley \& Yovanoff, 1996; Kyriacou, 2001; Anthoniou et al., 2006; 


\section{1 - 23 JUNE 2019}

Guthrie, 2006; S.S, Manabete et al., 2016). Teacher stress is the experience by a teacher; of unpleasant, negative emotions such as anxiety, tension, frustration, anger and depression, resulting from some aspect of their work as a teacher (Kyriacou, 2001; Reddy \& Anuradha, 2013). The problem of teacher stress has received increased attention among educational and psychological researchers over the years (Cooley \& Yovanoff, 1996; Farber, 1991; Friedman, 1993; Holland \& Michael, 1993; Lee \& Ashforth, 1996; Anderson et al., 1999). Stress and anxiety are inter connected and interdependent and difficult to differentiate them as the psychological and biological aspects are linked to each other (Wiedemann, 2001).

\section{Anxiety and Sahaja Yoga Meditation}

\subsection{Anxiety}

The term anxiety has been described as the emotional state which is expressed by psychological and physiological phenomena (Cohen et al., 1989). The concept of anxiety is broadly defined as 'the subjective feeling of tension, apprehension, nervousness, and worry associated with an arousal of the autonomic nervous system' (Spielberger, 1983). It is one of the most common psychological factor, personality concept, complex and unpleasant emotional state which place an important role in human behavior and it is often accompanied by restlessness, fatigue, problems in concentration and muscular tension (Costello et al., 2003; Gowri Naidu, 2016).

Anxiety further categorized as state anxiety and trait anxiety (Lufi et al., 2004). State anxiety can be defined as a transitory emotional state consisting of feelings of apprehension, nervousness, and physiological sequelae such as an increased heart rate or respiration (Spielberger, 1979). The trait anxiety is described as the individual's capability to perceive different situations from the environment like danger and threat. (Lufi et al.,, 2004). Trait anxiety represents a fairly stable characteristic related to personality (Wiedemann, 2001). On the other hand, state anxiety is described as the perception of individual's emotional situation. Normally little anxiety or stress works as a positive influence, but excessive amount of anxiety may leads to a disorder.

\subsection{Sahaja Yoga Meditation}

Meditation is a systematic narrowing of attention that slows the metabolism and helps produce feelings of relaxation (Rathus, 1997; Gundumogula \& Prusty, 2018). Meditation has been used to decrease the negative effects of stress on the nervous system, thereby increasing the individual's capacity to resist stress and respond adaptively to the work environment (Shapiro \& Walsh, 1984; Swanson \& Oates, 1989). During the past 25 years, the emergence of complementary and alternative medicine therapies as useful and effective therapeutic tools in conventional medicine has led to the exploration of meditation for treating and managing a variety of illnesses (Beauchemin et al., 2008). Meditation has been effective in decreasing both state anxiety (DeBerry et al, 1989) and trait anxiety (Goleman \& Schwartz, 1976).

In the present research meditative teachers have been practicing Sahaja Yoga meditation (SYM) atleast for the last 10 years. SYM is founded on the principle that 
the path to achieving peace and harmony in the world begins with each individual establishing a higher sense of awareness and suble self-knowledge. It works by balancing the energy of the body on a subtle level and connecting the individual with the universal living consciousness (Choudary etal., 2012). It has been proved that SYM is an effective tool: for promoting mental health and stress reduction (Manocha et al., 2009), to prevent of cadiovascular diseases and high blood pressure (Rai, 1993), to control asthma (Manocha et al., 2002), to increase of Grey Matter (Hernandez et al., 2016), to make positive influence on ADHD children (Harrison et al., 2003), for quality of life, functional health and wellbeing (Manocha et at., 2012), as a complimentary therapy in the management of cardiovascular diseases, diabetes and stress related disorders (Gupta et al., 2015), for its beneficial effects on some organ systems includeing cardiovascular system (Yalta et al., 2011), occupational health (Manocha et al., 2011), for constant downfall of anxiety and depression level of the individual (Sharma et al., 2005).

\section{Objectives and Hypothesis of the Study}

\subsection{Objective}

The present study endeavours to find out whether the Sahaja Yoga Meditation has any significant impact on the state trait anxiety level among the government school teachers.

\subsection{Hypothesis}

There is no significant difference between meditative and non-meditative teachers in their State Anxiety level.

There is no significant difference between meditative and non-meditative teachers in their Trait Anxiety level.

There is no significant difference between meditative and non-meditative teachers in their Trait Anxiety level based on their age and gender.

\section{Methodology}

\subsection{Sample}

For the selection of samples purposive sampling technique has been used in the present study. It consists of 60 government school teachers; out of these 35 male and 25 female teachers are chosen from East Godavari District, Andhra Pradesh State, India. Again it is subdivided into 30 Sahaja Yoga meditation practising teachers, who are practicing Sahaja Yoga meditation for 10 years or above and 30 non-meditative practitioner teachers. Their mean age is $47 \mathrm{yrs}$.

\subsection{Tool used}

The data for the present study was collected with the help of Sanjay Vohra (2001) State-Trait Anxiety Test which intends to assess the State-Trait Anxiety. It measures State-Trait Anxiety in five dimensions- Guilt Proneness $(\mathrm{Gp})$, Maturity (Ma), Suspiciousness(Su), Self-Control(Sc) and Tension(Tn) which contains immediate 


\section{1 - 23 JUNE 2019 \\ VIENNA, AUSTRIA}

manifest content suggesting psychiatric symptoms of anxiety, to a total number of 40 items.

\subsection{Data Collection}

Data is collected through questionnaire from government school teachers in East Godavari District, Andhra Pradesh, India. Teachers are approached individually, the objective and the purpose of the research are explained and they are asked to respond each statement truthfully. All the teachers, who are willing to participate in it voluntarily, are given the questionnaire to fill. Investigator has assured the confidentiality of their responses.

\section{Results and Discussion}

Table 1: Number and percentage of the social background of meditative teachers and non-meditative teachers $(N=60)$

\begin{tabular}{|l|l|c|c|c|c|c|}
\hline \multirow{2}{*}{$\begin{array}{l}\text { Sl. } \\
\text { No. }\end{array}$} & Variables & categories & $\begin{array}{c}\text { No. of non- } \\
\text { meditative } \\
\text { teachers }\end{array}$ & $\begin{array}{c}\text { \% of non- } \\
\text { meditative } \\
\text { teachers }\end{array}$ & $\begin{array}{c}\text { No. of } \\
\text { meditative } \\
\text { teachers }\end{array}$ & $\begin{array}{c}\text { \% of } \\
\text { meditative } \\
\text { teachers }\end{array}$ \\
\hline \multirow{2}{*}{1.} & \multirow{2}{*}{ Gender } & Male & 16 & $53.3 \%$ & 19 & $63.3 \%$ \\
\cline { 3 - 7 } & Female & 14 & $46.7 \%$ & 11 & $36.7 \%$ \\
\hline \multirow{2}{*}{ Age } & $35-39$ & 8 & $26.7 \%$ & 6 & $20.0 \%$ \\
\cline { 3 - 7 } & $40-44$ & 4 & $13.3 \%$ & 3 & $10.0 \%$ \\
\cline { 3 - 7 } & $45-49$ & 9 & $30.0 \%$ & 11 & $36.7 \%$ \\
\cline { 3 - 7 } & $50-54$ & 7 & $23.3 \%$ & 7 & $23.3 \%$ \\
\cline { 2 - 7 } & $55-59$ & 2 & $6.7 \%$ & 3 & $10.0 \%$ \\
\hline
\end{tabular}

If we consider the age group, the total sample distributes between the age groups of 35 to 59 for both the non-meditatve and meditative teachers, and again the age groups are distributed in 5 age groups and the class intervals for each group are also 5. Looking closely, we observe that highest percentage of teachers for both non-meditative and meditative teachers are $9(30 \%)$ and $11(36.7 \%)$ respectively belong to $45-49$ age group. Again the lowest number of teachers are included from the age group of 55-59;2 (6.7\%) and $3(10 \%)$ for non-meditative and meditative teachers respectively.

Table 2: Kolmogorov-Smirnov and Shapiro-Wilk of meditative teachers and non-meditative teachers $(N=60)$

\begin{tabular}{|l|l|r|r|r|r|r|r|}
\hline \multirow{2}{*}{ Group } & \multicolumn{2}{|c|}{ Kolmogorov-Smirnov } & \multicolumn{3}{c|}{ Shapiro-Wilk } \\
\cline { 3 - 8 } \multicolumn{2}{|c|}{} & \multicolumn{1}{|c|}{ Statistic } & \multicolumn{1}{c|}{ df } & Significane & Statistic & \multicolumn{1}{c|}{ df } & Significane \\
\hline \multirow{2}{*}{ meditatitve } & Age & .112 & 30 & $.200^{*}$ & .954 & 30 & .211 \\
\cline { 2 - 8 } & sexr & .406 & 30 & .000 & .612 & 30 & .000 \\
\hline & Age & .134 & 30 & .180 & .931 & 30 & .053 \\
\hline
\end{tabular}




\section{1 - 23 JUNE 2019}

\begin{tabular}{|l|l|r|r|r|r|r|r|}
\hline $\begin{array}{l}\text { Non } \\
\text { meditative }\end{array}$ & sexr & .354 & 30 & .000 & .637 & 30 & .000 \\
\hline
\end{tabular}

Figure 1: Q-Q-Diagrams of Age of the meditative teachers and non-meditative teachers $(N=60)$
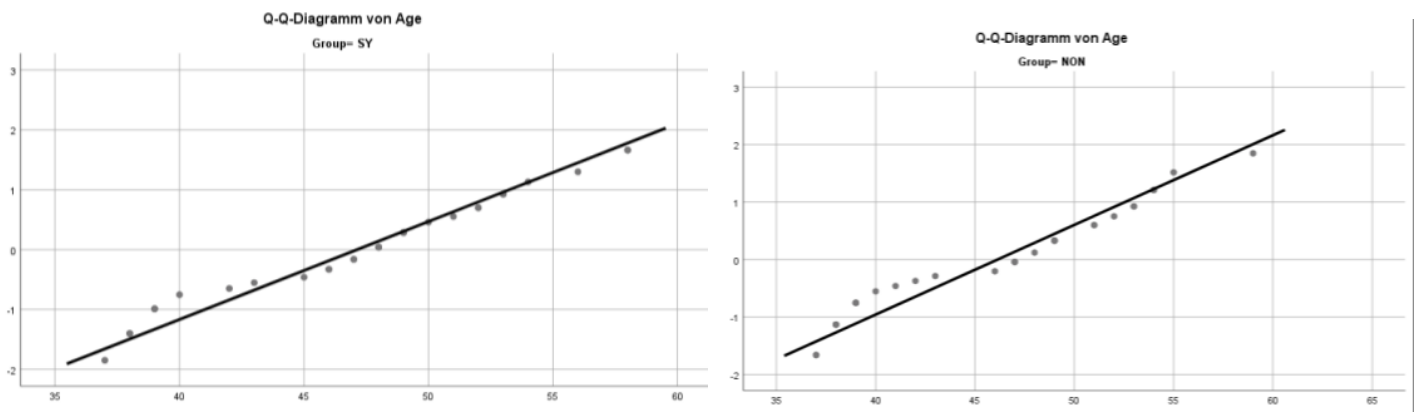

Table 3: t-test for independent samples for Meditation Practicing (non-meditative teachers, meditative teachers) on different dimensions of Anxiety

\begin{tabular}{|l|l|c|r|r|l|}
\hline Variable & Practicing Meditation & $\begin{array}{l}\text { Number } \\
\text { of cases }\end{array}$ & \multicolumn{1}{l|}{ Mean } & Std. Deviation & \multicolumn{1}{l}{$\begin{array}{l}\text { Std. Error } \\
\text { Mean }\end{array}$} \\
\hline \multirow{2}{*}{ guilt proneness } & non-meditative teachers & 30 & 19.5667 & 2.77530 & .50670 \\
\cline { 2 - 6 } & meditative teachers & 30 & 14.5667 & 3.20219 & .58464 \\
\hline \multirow{2}{*}{ Maturity } & non-meditative teachers & 30 & 9.4667 & 2.06336 & .37672 \\
\cline { 2 - 6 } & meditative teachers & 30 & 7.8000 & 1.32353 & .24164 \\
\hline \multirow{2}{*}{ self control } & non-meditative teachers & 30 & 11.7667 & 2.83675 & .51792 \\
\cline { 2 - 6 } & meditative teachers & 30 & 9.5667 & 2.35889 & .43067 \\
\hline \multirow{2}{*}{ suspiciousness } & non-meditative teachers & 30 & 7.1000 & 1.51658 & .27689 \\
\cline { 2 - 6 } & meditative teachers & 30 & 5.1667 & 1.44039 & .26298 \\
\hline \multirow{2}{*}{ Tension } & non-meditative teachers & 30 & 17.4000 & 2.74929 & .50195 \\
\cline { 2 - 6 } & meditative teachers & 30 & 13.7333 & 2.14851 & .39226 \\
\hline
\end{tabular}

Table 4: Leverne's Test for Equality of Variances

\begin{tabular}{|c|c|c|c|c|c|c|c|c|c|}
\hline \multirow[t]{2}{*}{ Variable } & \multirow[t]{2}{*}{ Variances } & \multirow[t]{2}{*}{ t value } & \multirow[t]{2}{*}{ Df } & \multirow{2}{*}{$\begin{array}{c}\text { Sig. } \\
(2- \\
\text { tailed } \\
)\end{array}$} & \multirow[t]{2}{*}{$\begin{array}{c}\text { Mean } \\
\text { Differenc } \\
\mathbf{e}\end{array}$} & \multirow{2}{*}{$\begin{array}{c}\text { Std. } \\
\text { Error } \\
\text { Differenc } \\
\mathrm{e}\end{array}$} & \multicolumn{2}{|c|}{$\begin{array}{c}\text { 95\% Confidence } \\
\text { Interval of the } \\
\text { Difference }\end{array}$} & \multirow[t]{2}{*}{$\begin{array}{c}\text { Effect } \\
\text { size }\end{array}$} \\
\hline & & & & & & & Lower & Upper & \\
\hline guilt proneness & Not Equal & 6.463 & 56.852 & .000 & 5.00000 & .77366 & 3.45069 & 6.54931 & 1.18 \\
\hline Maturity & Not Equal & 3.724 & 49.409 & .001 & 1.66667 & .44756 & .76746 & 2.56588 & 0.96 \\
\hline self control & Not Equal & 3.266 & 56.132 & .002 & 2.20000 & .67358 & .85072 & 3.54928 & 0.84 \\
\hline
\end{tabular}




\section{SOCIAL SCIENCE, HUMANITIES \& EDUCATION}

21 - 23 JUNE 2019

VIENNA, AUSTRIA

\begin{tabular}{|l|c|c|c|c|c|c|c|c|c|}
\hline Suspiciousness & Not Equal & 5.063 & 57.847 & .000 & 1.93333 & .38187 & 1.16890 & 2.69777 & 1.31 \\
\hline Tension & Not Equal & 5.756 & 54.799 & .000 & 3.66667 & .63704 & 2.38990 & 4.94343 & 1.49 \\
\hline
\end{tabular}

From the above table, it can be observed that there exist significance differences in the anxiety level of Non-Meditativeand Meditative teachers according to different dimensions. Statistically we found 2-tailded significant differences in all dimensions.

Table 5: t-test for independent samples for meditation practicing (non-meditative teachers, meditative teachers) on Trait and State anxiety levels

\begin{tabular}{|l|l|l|l|l|l|}
\hline Variable & practicing meditation & N & Mean & Std. Deviation & $\begin{array}{l}\text { Std. } \\
\text { Error } \\
\text { Mean }\end{array}$ \\
\hline Trait anxiety score & non-meditative teachers & 30 & 33.2667 & 3.59054 & .65554 \\
\cline { 2 - 6 } & meditative teachers & 30 & 26.0667 & 5.25182 & .95885 \\
\hline \multirow{2}{*}{ State anxiety score } & non-meditative teachers & 30 & 32.0333 & 4.96528 & .90653 \\
\cline { 2 - 6 } & meditative teachers & 30 & 24.7667 & 3.87462 & .70740 \\
\hline
\end{tabular}

Figure 2: Trait \& State Anxiety Mean Scores of meditative and non-meditative teachers

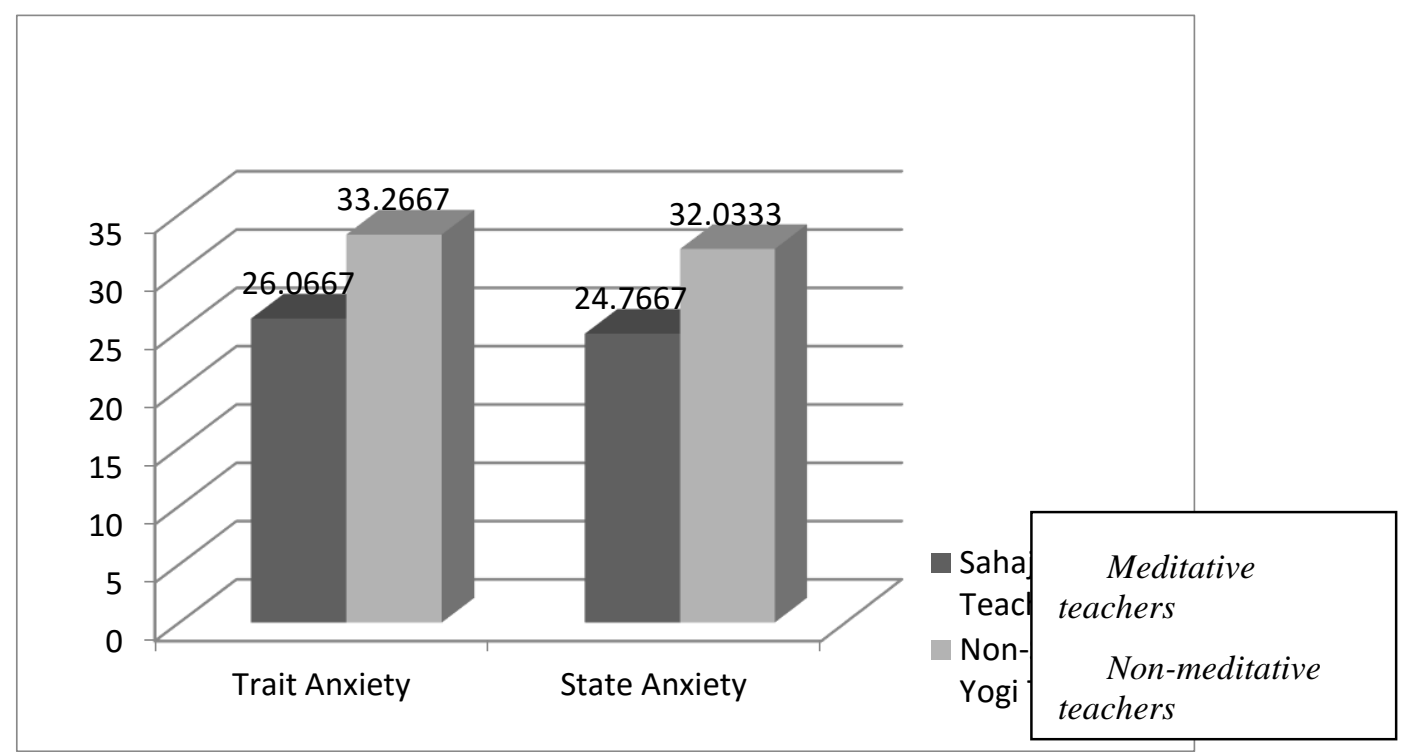

Table 6: Leverne's Test for Equality of Variances

\begin{tabular}{|l|l|l|l|l|l|l|l|l|}
\hline Variable & Variance & t value & df & $\begin{array}{c}\text { Sig. (2- } \\
\text { tailed) }\end{array}$ & $\begin{array}{c}\text { Mean } \\
\text { Difference }\end{array}$ & $\begin{array}{c}\text { Std. Error } \\
\text { Difference }\end{array}$ & $\begin{array}{c}\text { 95\% Confidence } \\
\text { Interval of the } \\
\text { Difference }\end{array}$ & $\begin{array}{c}\text { Effect } \\
\text { size }\end{array}$ \\
\cline { 3 - 5 } & & & Lower & Upper & \\
\hline
\end{tabular}




\section{1 - 23 JUNE $2019 \quad$ VIENNA, AUSTRIA}

\begin{tabular}{|l|c|c|c|c|c|c|c|c|c|}
\hline $\begin{array}{l}\text { trait } \\
\text { anxiety } \\
\text { score }\end{array}$ & Not Equal & 6.199 & 51.249 & .000 & 7.20000 & 1.16152 & 4.86843 & 9.53157 & 1.60 \\
\hline $\begin{array}{l}\text { state } \\
\text { anxiety } \\
\text { score }\end{array}$ & Not Equal & 6.320 & 54.765 & .000 & 7.26667 & 1.14988 & 4.96203 & 9.57130 & 1.63 \\
\hline
\end{tabular}

From the above table it is clearly visible that there exist significance differences in trait and state anxiety level between non-sahaja yogia and sahja yogi teachers at 2-tailed significance level.

Trait Anxiety Level: These are the anxiety levels which are intrinsic in nature and hence quite unrealized by the respondents. Mostly found in sub-conscious level of an individual. If we observe the above table, we can notice that the scores varied for the groups (non-meditative teachers- $\mathrm{M}=33.26, \mathrm{SD}=3.590$; meditative teachers- $\mathrm{M}=$ $26.06, \mathrm{SD}=5.251)$. At an alpha of .05 , the analysis indicated a statistically significant difference among the groups, $\mathrm{t}(51.2)=6.199, \mathrm{p}=.000$, effect size $=1.60 \mathrm{SD}$. It is clearly observed that the value of effect size is higher than the value 0.8 of Cohen's $d$ and thus, it can be deduced that non-sahaji group experiences very high trait anxiety level than sahaji teacher's group.

State Anxiety Level: On the other hand, state anxiety level is extrinsic and felt by the respondents directly. Consciously an individual could feel his/her anxiety level. Similarly the trait anxiety, state anxiety level reveals that the scores varied for the groups (non-meditative teachers- $\mathrm{M}=32.03, \mathrm{SD}=4.965$; meditative teachers- $\mathrm{M}=$ $24.76, \mathrm{SD}=3.874)$. At an alpha of .05 , the analysis indicated a statistically significant difference among the groups, $\mathrm{t}(54.7)=6.320, \mathrm{p}=.000$, effect size $=1.63 \mathrm{SD}$. It is also revealing that the effect size value is higher than the value 0.8 of Cohen's $d$ and can be interpreted as non-sahaji group experiences very high state anxiety level than sahaji teacher's group.

Table 7: t-test for independent samples for meditation practicing (non-meditative, meditative teachers) on over all anxiety levels

\begin{tabular}{|l|l|c|c|c|c|}
\hline Variable & Practicing Meditation & Number & Mean & Std. Deviation & $\begin{array}{l}\text { Std. Error } \\
\text { Mean }\end{array}$ \\
\hline Overall Anxiety level & non-meditative teachers & 30 & 65.3000 & 7.16385 & 1.30793 \\
\hline & meditative teachers & 30 & 50.8333 & 8.53020 & 1.55739 \\
\hline
\end{tabular}

Figure 3: Mean of t-test for independent samples for meditation practicing (non-meditative, meditative teachers) on over all anxiety levels 


\section{1 - 23 JUNE $2019 \quad$ VIENNA, AUSTRIA}

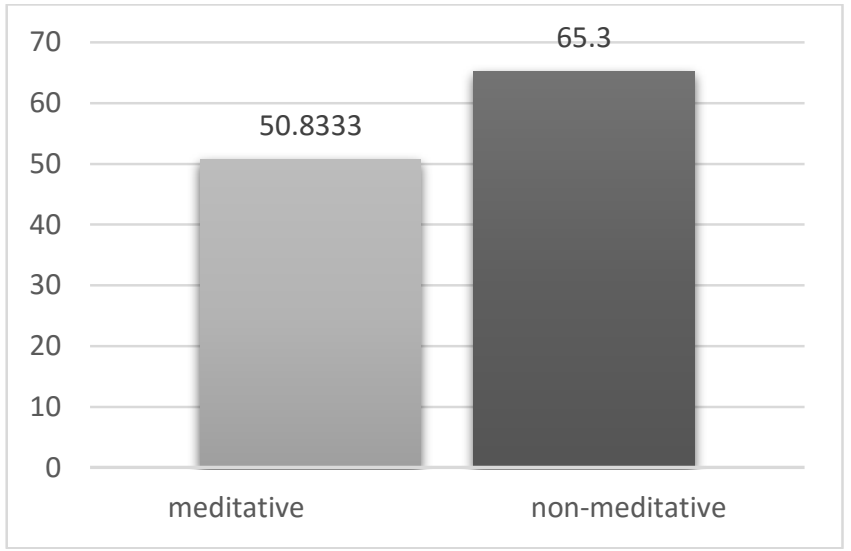

Table 8: Leverne's Test for Equality of Variances

\begin{tabular}{|l|l|l|l|l|l|l|l|l|}
\hline \multicolumn{2}{|l|}{ Variance } & t value & Df & $\begin{array}{c}\text { Sig(2- } \\
\text { tailed) }\end{array}$ & $\begin{array}{c}\text { Mean } \\
\text { Difference }\end{array}$ & $\begin{array}{l}\text { Std. Error } \\
\text { Difference }\end{array}$ & $\begin{array}{c}\text { 95\% Confidence } \\
\text { Interval of the } \\
\text { Difference }\end{array}$ & $\begin{array}{c}\text { Effect } \\
\text { size }\end{array}$ \\
\cline { 5 - 8 } & & & & & Lower & Upper & \\
\hline & Not Equal 7.113 & 56.318 & .000 & 14.46667 & 2.03376 & 10.39307 & 18.54026 & 1.84 \\
\hline
\end{tabular}

In the above table, the overall anxiety level shows that the scores varied for the groups (non-meditative teachers- $\mathrm{M}=65.30, \mathrm{SD}=4.965$; meditative teachers- $\mathrm{M}=24.76, \mathrm{SD}=$ 7.163). At an alpha of .05, the analysis indicated a statistically significant difference among the groups, $\mathrm{t}(56.3)=7.113, \mathrm{p}=.000$, effect size $=1.84 \mathrm{SD}$. Here also the effect size value is higher than the value 0.8 of Cohen's $d$ and hence interpreted as non-sahaji group experiences very high overall anxiety level than sahaji teacher's group. The reason for this difference can be, by practicing Sahaja Yoga Meditation, an individual get physical, mental and emotional balance in their life; which results in decrease in the above discussed all the dimensions of the anxiety enabling an individual feel relaxed and realistic; free from stress and anxiety. This result is also agreeing with Flook Lisa and et al, who conducted a pilot study to assess the effect of mindful meditation on stress, burn out and teaching efficacy. Their study revealed that this meditation practice has reduced significantly psychological symptoms and burn out. Similarly Gouda Saraha \& et al conducted a pilot study on benefit of mindful meditation on stress reduction of school students and teachers. Their result is also coinciding with our result.

Table 9: t-test for independent samples for Gender (male, Female) on over all anxiety levels

\begin{tabular}{|l|l|l|l|l|l|}
\hline Variable & Gender & N & Mean & Std. Deviation & Std. Error Mean \\
\hline $\begin{array}{l}\text { Overall } \\
\text { Anxiety level }\end{array}$ & Male & 35 & 58.5143 & 10.80678 & 1.82668 \\
\hline
\end{tabular}


21 - 23 JUNE 2019
VIENNA, AUSTRIA

\begin{tabular}{|l|l|l|l|l}
\hline Female & 25 & 57.4400 & 10.70467 & 2.14093 \\
\hline
\end{tabular}

Table 10: Leverne's Test for Equality of Variances

\begin{tabular}{|l|l|l|l|l|l|l|l|}
\hline Variance & $\begin{array}{c}\mathbf{t} \\
\text { value }\end{array}$ & Df & $\begin{array}{c}\text { Sig. } \\
\text { (2-tailed) }\end{array}$ & Mean Difference & $\begin{array}{r}\text { Std. Error } \\
\text { Difference }\end{array}$ & \multicolumn{2}{|c|}{$\begin{array}{c}\text { 95\% Confidence } \\
\text { Interval of the Difference }\end{array}$} \\
\cline { 3 - 7 } & 381 & 58 & 705 & 1.07429 & 2.81885 & 4.56825 & 5.71682 \\
\hline
\end{tabular}

The above table reveals that the scores of the groups (male $-\mathrm{M}=58.51, \mathrm{SD}=10.806$; Female- $\mathrm{M}=57.44, \mathrm{SD}=710.704)$. At an alpha of .05 , the analysis indicated not a statistically significant difference exist among the groups, $\mathrm{t}(58)=.381, \mathrm{p}=.705$. This reveals that there is no significant difference between Male and Female teachers. As the work load is equal for both male and female teachers, the result would have come so.

Table 10: One way - ANOVA analysis Age group (35-39, 40-44, 45-49, 50-54, 55 59) on Overall Anxiety level

\begin{tabular}{|c|c|c|c|c|c|c|c|c|}
\hline \multirow[t]{2}{*}{$\begin{array}{l}\text { Age } \\
\text { Group }\end{array}$} & \multirow[t]{2}{*}{$\mathbf{N}$} & \multirow[t]{2}{*}{ Mean } & \multirow[t]{2}{*}{$\begin{array}{c}\text { Std. } \\
\text { Deviation }\end{array}$} & \multirow[t]{2}{*}{ Std. Error } & \multicolumn{2}{|c|}{$\begin{array}{l}95 \% \text { Confidence } \\
\text { Interval for Mean }\end{array}$} & \multirow[t]{2}{*}{ Minimum } & \multirow[t]{2}{*}{ Maximum } \\
\hline & & & & & Lower Bound & $\begin{array}{l}\text { Upper } \\
\text { Bound }\end{array}$ & & \\
\hline $35-39$ & 14 & 58.0714 & 9.21090 & 2.46172 & 52.7532 & 63.3896 & 43.00 & 69.00 \\
\hline $40-44$ & 7 & 62.1429 & 12.82483 & 4.84733 & 50.2819 & 74.0038 & 46.00 & 84.00 \\
\hline $45-49$ & 20 & 55.8000 & 9.95040 & 2.22498 & 51.1431 & 60.4569 & 44.00 & 83.00 \\
\hline $50-54$ & 14 & 60.7857 & 11.10217 & 2.96718 & 54.3755 & 67.1959 & 44.00 & 75.00 \\
\hline $55-59$ & 5 & 53.8000 & 13.70036 & 6.12699 & 36.7888 & 70.8112 & 43.00 & 76.00 \\
\hline Total & 60 & 58.0667 & 10.68639 & 1.37961 & 55.3061 & 60.8273 & 43.00 & 84.00 \\
\hline
\end{tabular}

Table 11: ANOVA

\begin{tabular}{|c|c|c|c|c|c|}
\hline & Sum of Squares & df & Mean Square & F & Sig. \\
\hline Between Groups & 413.590 & 4 & 103.398 & .899 & .471 \\
\hline Within Groups & 6324.143 & 55 & 114.984 & & \\
\hline Total & 6737.733 & 59 & & & \\
\hline
\end{tabular}

Table 12: LSD Post Hoc, Dependent Variable: total interval

\begin{tabular}{|c|c|c|c|c|c|c|}
\hline (I) age & (J) age & $\begin{array}{c}\text { Mean Difference } \\
\text { (I-J) }\end{array}$ & Std. Error & Sig. & \multicolumn{2}{|c|}{ 95\% Confidence Interval } \\
\cline { 5 - 7 } & & -4.07143 & 4.96382 & .416 & -14.0191 & 5.8763 \\
\hline $35-39$ & $40-44$ & \multicolumn{2}{|c|}{} & \multicolumn{2}{|c|}{ Lower Bound } & Upper Bound \\
\hline
\end{tabular}




\section{SOCIAL SCIENCE, HUMANITIES \& EDUCATION}

\section{1 - 23 JUNE $2019 \quad$ VIENNA, AUSTRIA}

\begin{tabular}{|c|c|c|c|c|c|c|}
\hline \multirow{5}{*}{} & $45-49$ & 2.27143 & 3.73663 & .546 & -5.2169 & 9.7598 \\
\cline { 2 - 7 } & $50-54$ & -2.71429 & 4.05294 & .506 & -10.8366 & 5.4080 \\
\cline { 2 - 7 } & $55-59$ & 4.27143 & 5.58660 & .448 & -6.9244 & 15.4672 \\
\hline $40-44$ & $35-39$ & 4.07143 & 4.96382 & .416 & -5.8763 & 14.0191 \\
\cline { 2 - 7 } & $45-49$ & 6.34286 & 4.70909 & .184 & -3.0944 & 15.7801 \\
\cline { 2 - 7 } & $50-54$ & 1.35714 & 4.96382 & .786 & -8.5906 & 11.3049 \\
\cline { 2 - 7 } & $55-59$ & 8.34286 & 6.27879 & .189 & -4.2401 & 20.9258 \\
\hline $45-49$ & $35-39$ & -2.27143 & 3.73663 & .546 & -9.7598 & 5.2169 \\
\cline { 2 - 7 } & $40-44$ & -6.34286 & 4.70909 & .184 & -15.7801 & 3.0944 \\
\cline { 2 - 7 } & $50-54$ & -4.98571 & 3.73663 & .188 & -12.4741 & 2.5027 \\
\cline { 2 - 7 } & $55-59$ & 2.00000 & 5.36154 & .711 & -8.7448 & 12.7448 \\
\hline $50-54$ & $35-39$ & 2.71429 & 4.05294 & .506 & -5.4080 & 10.8366 \\
\cline { 2 - 7 } & $40-44$ & -1.35714 & 4.96382 & .786 & -11.3049 & 8.5906 \\
\cline { 2 - 7 } & $45-49$ & 4.98571 & 3.73663 & .188 & -2.5027 & 12.4741 \\
\cline { 2 - 7 } & $55-59$ & 6.98571 & 5.58660 & .216 & -4.2101 & 18.1815 \\
\hline $55-59$ & $35-39$ & -4.27143 & 5.58660 & .448 & -15.4672 & 6.9244 \\
\cline { 2 - 7 } & $40-44$ & -8.34286 & 6.27879 & .189 & -20.9258 & 4.2401 \\
\cline { 2 - 7 } & $45-49$ & -2.00000 & 5.36154 & .711 & -12.7448 & 8.7448 \\
\cline { 2 - 7 } & $50-54$ & -6.98571 & 5.58660 & .216 & -18.1815 & 4.2101 \\
\hline
\end{tabular}

Looking at the above table, we can interpret that the scores for the groups (35-39$\mathrm{M}=58.07, \mathrm{SD}=9.210 ; 40-44-\mathrm{M}=62.14, \mathrm{SD}=12.824 ; 45-49-\mathrm{M}=55.80, \mathrm{SD}=$ $9.950 ; 50-54-\mathrm{M}=60.78, \mathrm{SD}=11.102 ; 55-59-\mathrm{M}=53.80, \mathrm{SD}=13.700)$. At an alpha of .05 , the analysis indicated not a statistically significant difference exist among the groups, $\mathrm{F}$ ( 4 between the groups and 55 within the groups $)=.899, \mathrm{p}=.471$. This shows that there is no significant difference among the different age groups of teachers in their anxiety levels. The reason may be that all the teachers irrespective of their age get the equal work load and responsibilities in their teaching profession.

\section{Conclusion}

The data of the mean of the t-test on over all anxiety levels showed approx. 30\% higher values of anxiety for the non-meditative teachers compared to the teachers practicing Sahaja Yoga meditation. The present study concludes that according to the findings Sahaja Yoga meditation may be a good method to deal with the anxiety levels in general and as well with state as with trait anxieties. As Sahaja Yoga Meditation practice helps the teachers to overcome their anxiety level and hence it can be used as a therapeutic technique for teachers to keep their mental health peaceful and balanced

\section{References}

Anderson, V.L. Levinson E.M., Barker, W. \& Kiewra K.R., 1999. School Psychology Quarterly, 14(1), pp. 3-25.

Anthoniou, A. S., Polychroni, F. \& Vlachakis, A. N. (2006). Gender and age differences in occupational stress and professional burnout between primary and highschool teachers in Greece. Journal of Managerial Psychology, 21(7), 682-690. 


\section{1 - 23 JUNE $2019 \quad$ VIENNA, AUSTRIA}

Beauchemin. J, Tiffany L.H., Fiona P, 2008. Mindfulness Meditation may lessen Anxiety, Promote Social Skills, and Improve Academic Performance among Adoleschents with Learning Disabilities, Complementary Health Practice Review, Sage Publications. DOI: 10.1177/1533210107311624

Cacha, F. B. (1981). Teacher burnout: Causes and solutions. Kappa Delta Pi Record. $18,23,26-27$.

Cohen, A., Yaakobi, D., Porat, A. B., \& Chayoth, R. (1989). The effects of biology games on studentse anxiety and in their achievement. International Journal of Science Education, 11(4), 387-394.

Cooley, E., \& Yovanoff, P. (1996). Supporting professionals-at-risk: Evaluating interventions to reduce burnout and improve retention of special educators. Exceptional Children, 62, 336-356.

Costello, E. J., Mustillo, S., Erkanli, A, Keeler, G and Angold, A. (2003). Prevelance and development of Psychiatric disorders in childhood and adolescence. JAMA Psychiatry, 60(8).

DeBerry, S., Davis, S., \& Reinhard, K. E. (1989). A comparison of meditationrelaxation and cognitive/behavioral techniques for reducing anxiety and depression in a geriatric population. Journal of Geriatric Psychiatry, 2, 231-247.

Farber, B. A. (1991). Crisis in education: Stress and burnout in the American teacher. San Francisco: Jossey-Bass.

Friedman, I. A. (1993). Burnout in teachers: The concept and its unique core meaning. Educational and Psychological Measurement, 53, 1035-1045.

Goleman, D. J., \& Schwartz, G. E. (1976). Meditation as an intervention in stress reactivity. Journal of Consulting and Clinical Psychology, 44,456-466.

Gouda. Sarah, Luong. Minh T., Stefan Schmidt, and Joachim Bauer (2016). Students and Teachers Benefit from Mindfulness-Based Stress Reduction in a SchoolEmbedded Pilot Study. Frontiers in Psychology doi: 10.3389/fpsyg.2016.00590 Retrieved from https://www.ncbi.nlm.nih.gov/pmc/articles/PMC4845593/

Gowri Naidu, B. 2016. A comparative study of selected psychological variables among junior national level long jump and high jump athletes. International Journal of Physical Education, Sports and Health, 3(6), 88-91.

Gundumogula, M. \& Prusty, R. 2018. Developing Sustainability Mindsets- Effects of Meditative Practices on Sustainable Education, Journal of International Scientific Publications, 244-253.

Gupta, S., Shankar, V. and Lal, H. (2015). Effect of Sahaja Yoga on MDA and Blood Thiol Levels in Healthy Volunteers. International Journal of Basic and Applied Medical Sciences, [online] Volume 5 (1), 27-32. Available at http://www.cibtech.org/JMEDICAL-SCIENCES/PUBLICATIONS/2015/Vol_5_No_1/04-JMS-003-

SAMRTA-YOGA-VOLUNTEERS.pdf 


\section{1 - 23 JUNE $2019 \quad$ VIENNA, AUSTRIA}

Guthrie, R. (2006). Teachers and stress. Australia and New Zealand. Journal of Law and Education, 11(1), 5-18.

Harrison, L., Manocha, R. and Rubia, K. (2003). Sahaja Yoga Meditation as a Family Treatment Program for Attention Deficit Hyperactivity Disorder Children. Journal of Clinical Psychology and Psychiatry, 9(4), 479-97.

Holland, P. J., \& Michael, W. B. (1993). The concurrent validity of the Holland Burnout assessment survey for a sample of middle school teachers. Educational and Psychological Measurement, 53, 1067-1078.

Choudary. R, Singh. V \& Singh. G.K. (2012). A Study of Trend of the Effect of Sahaja Yoga Meditation on Rhythmic Ability, Indian Journal of Physical Education and Yogic Sciences, 2(2), 46-51.

Kyriacou, C. (2001). Teacher stress: Directions for future research. Educational Review, 53(1), 27-35.

Lee, R. T., \& Ashforth, B. E. (1996). A meta-analytic examination of the correlates of the three dimensions of job burnout. Journal of Applied Psychology, 81(2), 123134.

Lisa, Simon B. Goldberg, Laura Pinger, Katherine Bonus, and Richard J. Davidson (2013). Mindfulness for Teachers: A pilot study to assess effects on stress, burnout and teaching efficacy. HHS Public Access 7(3) doi: 10.1111/mbe.12026 Retrived from https://www.ncbi.nlm.nih.gov/pmc/articles/PMC3855679/

Lufi, D., Okasha, S., \& Cohen, A. (2004). Test anxiety and its effect on the personality of students with learning disabilities. Learning Disability Quarterly, 27(3), 176-184.

Manocha, R., Black, D. and Wilson, L. (2012) Quality of Life and Functional Health Status of Long-Term Meditators. Evidence-Based Complementary and Alternative Medicine, [online] Volume 2012. Article ID 350674. Available at https://www.hindawi.com/journals/ecam/2012/350674/

Manocha, R., Black, D., Sarris, J. and Stough, C. (2011). A Randomized, Controlled Trial of Meditation for Work Stress, Anxiety and Depressed Mood in FullTime Workers. Evidence-Based Complementary and Alternative Medicine. [online] Volume 2011 p.1-8. Available at https://www.researchgate.net/publication/51455276_A_Randomized_Controlled_Tria 1_of_Meditation_for_Work_Stress_Anxiety_and_Depressed_Mood_in_FullTime_Workers

Manocha, R., Gordon, A., Black, D., Malhi, G. and Seidler, R. (2009). Using Meditation for less Stress and better Wellbeing - Evaluation of a Seminar for GPs. Australian Family Physician, [online] Volume 38(6), 369-464. Available at https://www.racgp.org.au/download/Documents/AFP/2009/June/200906manocha.pdf

Manocha, R., Marks, G., Kenchington, P., Peters D. and Salome, C. (2002). Sahaia yoga in the management of moderate to severe asthma: a randomised controlled trial. Thorax, 2002 Feb;57(2):110-5. 


\section{$21-23$ JUNE 2019 \\ VIENNA, AUSTRIA}

Paine, W. S. (1981). The burnout phenomenon. Vocational Education,56X8), 30-33. perspective. Teachers College Record, 83, 235-243. Landsman, L. (1978). Is teaching hazardous to your health? Today's Education, 6 7(2), 48-50.

Russell, Daniel \& Altmaier, Elizabeth \& Van Velzen, Dawn. (1987). Job-Related Stress, Social Support, and Burnout Among Classroom Teachers. The Journal of applied psychology. 72. 269-74. 10.1037//0021-9010.72.2.269.

S.S, Manabete \& C.A, John \& Makinde, Abraham \& S.T, Duwa. (2016). Job Stress among School Administrators and Teachers in Nigerian Secondary Schools and Technical Colleges. International Journal of Education, Learning and Development, 4. $1-9$.

Sharma, VK. Das, S. Mondal, S. Goswampi, U. Gandhi, A. (2005). Effect of Sahaj Yoga on depressive disorders. Indian J Physiol Pharmacol. Volume 49(4):462-8. Available at https://www.ncbi.nlm.nih.gov/pubmed/16579401

Spielberger, C. D. (1979). Understanding Stress and Anxiety, Harper and Row: New York.

Spielberger, C. D. 1983. Manual for the State-Trait Anxiety Inventory (form Y). Palo Alto, CA: Consulting Psychologists Press.

Wiedemann, K. (2001). Anxiety and Anxiety Disorders. International Encyclopedia of the Social \& Behavioral Sciences, 560-567.doi:10.1016/b0-08-043076-7/03760-8

Yalta, K. Sivri, N. and Yetkin E. (2011). Sahaja yoga: A unique adjunctive approach for the management of cardiac arrhythmias? International journal of cardiology, $\begin{array}{lllll}\text { Volume } & 152(1), & \text { P. } & 99-100 & \text { Available }\end{array}$ https://www.internationaljournalofcardiology.com/article/S0167-5273(11)00690$5 / \mathrm{pdf}$ 